\title{
Reconstructing Ancient Foodways at the Jones Mill Site (3HS28), Hot Spring County, Arkansas
}

\author{
Mary Beth D. Trubitt \\ Arkansas Archeological Survey, HSU Research Station \\ Kathryn Parker \\ Lucretia Kelly
}

Follow this and additional works at: https://scholarworks.sfasu.edu/ita

Part of the American Material Culture Commons, Archaeological Anthropology Commons, Environmental Studies Commons, Other American Studies Commons, Other Arts and Humanities Commons, Other History of Art, Architecture, and Archaeology Commons, and the United States History Commons

Tell us how this article helped you.

This Article is brought to you for free and open access by the Center for Regional Heritage Research at SFA ScholarWorks. It has been accepted for inclusion in Index of Texas Archaeology: Open Access Gray Literature from the Lone Star State by an authorized editor of SFA ScholarWorks. For more information, please contact cdsscholarworks@sfasu.edu. 


\section{Reconstructing Ancient Foodways at the Jones Mill Site (3HS28), Hot Spring}

County, Arkansas

\section{Creative Commons License}

\section{(c) (1) \&}

This work is licensed under a Creative Commons Attribution-NonCommercial 4.0 International License 


\title{
RECONSTRUCTING ANCIENT FOODWAYS AT THE JONES MiLl SITE (3HS28), Hot SPRING CounTy, ARKansaS
}

\author{
Mary Beth Trubitt, Kathryn Parker, and Lucretia Kelly
}

\begin{abstract}
Analyses of botanical and faunal samples and a new radiocarbon date provide a detailed picture of Indian foodways at the Jones Mill site on the Ouachita River in Arkansas. Hunting, plant processing, and fishing with nets is seen from Middle Archaic artifacts and features. Burned hickory nutshell found among clusters of fire-cracked rock shows the importance of nut masts as food between 6000-4300 B.C. By 1450 A.D., a more substantial community of people lived at Jones Mill. Refuse associated with traces of a Caddo period house provided direct evidence for the cultivation of maize and native Eastern Complex starchy seed crops and procurement of select wild plants and animals for food.
\end{abstract}

\section{Background and Excavation Overview}

Field excavations were conducted in 2007-2008 at Jones Mill (3HS28), a multicomponent site on the Ouachita River in west-central Arkansas (Figure 1). Trubitt directed Arkansas Archeological Survey/Society training programs at the site along with archaeological field schools held through University of Arkansas and Henderson State University. The research project is investigating the manufacture and trade of novaculite chipped stone tools particularly during the Middle Archaic period (circa 6000 - 3000 B.C.). Novaculite, now used for Arkansas whetstones, was an important raw material for local inhabitants (Trubitt et al. 2004). It was one of several rocks and minerals found in the Ouachita Mountains, specifically the Magnet Cove region, and transported down river to sites in Louisiana and Mississippi during the Archaic period (Brookes 1999; Gibson 1994, 1999; Jeter and Jackson 1994; Rolingson and Howard 1997; Webb 1977).

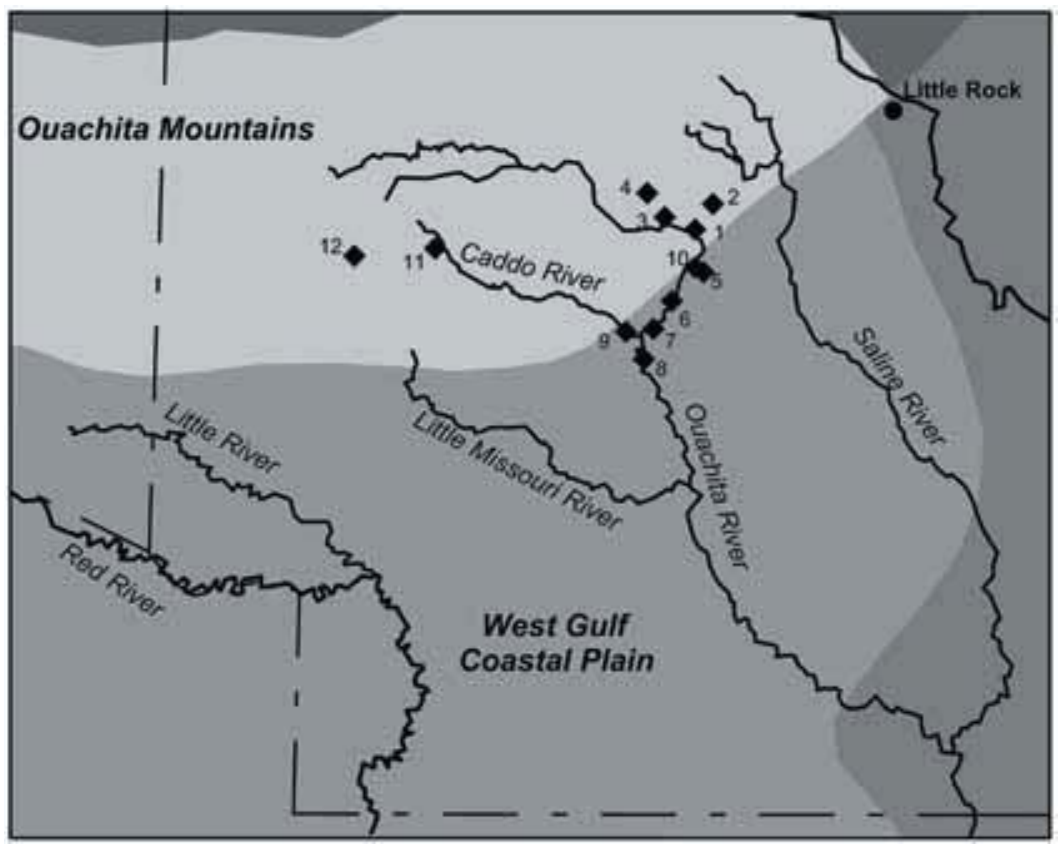

Figure 1. Regional map showing Jones Mill and other sites mentioned in text against major rivers and physiographic provinces in southwest Arkansas:

(1) Jones Mill (3HS28),

(2) 3GA48 quarry,

(3) 3GA23/Lawrence,

(4) 3GA22 quarry,

(5) 3HS551,

(6) Means,

(7) Cooper,

(8) Hardman,

(9) Caddo Valley Md.,

(10) Helm,

(11) Standridge,

(12) Winding Stair. 
The Jones Mill site is not a novaculite quarry itself, but lies about 7-10 km away from one of the largest quarry complexes in the Hot Springs area, the extensive Spanish Diggings quarries (3GA48/HS158/HS433) first described by Jenney (1891) and Holmes (1919), and more recently tested by Baker (1974) and mapped by Etchieson (1997). The situation of a large stratified site on the Ouachita River at the confluence of a creek that drains from a major ridgetop novaculite quarry is reminiscent of Harrington's (1920) "Deep Deposit" at the Lawrence site (3GA20/23/96/97) and the 3GA22 quarry in Hot Springs National Park (Holmes 1891, 1919; Trubitt 2005, 2007).

Previous field investigations at Jones Mill clearly showed the potential for uncovering deep and intact Archaic period deposits with cultural features. Excavations at the site were conducted in the early 1980s as part of cultural resource management testing by Archeological Assessments, Inc. (Bennett 1986). Using methods from surface collection and auger testing to hand excavation to backhoe trenching and mechanical stripping, that project confirmed 3HS28 as a large site with some vertical and horizontal separation of components. Most of the cultural features were identified in a block excavation on the site's north side, where archeologists found postmold patterns interpreted as three circular structures, as well as hearths, pits, and burials of four individuals (Bennett 1986:40-48). While no radiometric dates were obtained from that project, the artifact analyses indicated that a major Woodland period (Fourche Maline) component and a minor Caddo period occupation were represented by the midden and features. In excavation units further south, deposits with Middle and Late Archaic period diagnostics were uncovered to a depth of $1.2 \mathrm{~m}$. The 1980s testing did not identify many floral and faunal remains, in part because soils in this region are generally acidic, but also perhaps because of the processing techniques used (for example, waterscreening soil prior to flotation, Bennett 1986:114).

Since that time, construction has been done on the less significant part of the site while the landowner has protected the denser area of 3HS28. The site was listed on the National Register of Historic Places in 1988. More recent site visits during other cultural resource management projects expanded the site boundaries and recorded additional sites in the vicinity (Chapman 2004), as well as show the continuing impact from local artifact collectors.

Our field work at the site comes out of the novaculite quarry research design developed several years ago (Trubitt et al. 2004) and an interest in studying the organization of Archaic period novaculite tool production and exchange. Excavations at 3HS28 were geared towards identifying and dating the residues of residential, subsistence, and tool manufacturing activities, evaluating whether the site was occupied seasonally or year-round, and analyzing the organization of novaculite tool production. Over the two field seasons on the Jones Mill site, we excavated a total of $47 \mathrm{~m}^{3}$ in five trenches (Figure 2). In addition to public talks and presentations at professional conferences, several short articles have been published on the excavation results and radiocarbon dates (Brock 2009; Trubitt 2008, 2009a, 2009b, 2011). We are completing lab processing. The quantity of novaculite artifacts catalogued - over $1 / 2$ million pieces, mostly chipping debris - makes it clear that tool production was a major activity of the former residents.

We placed three excavation trenches on the site's west side in an area that had relatively thin layers with Caddo and Woodland period materials and a thick deposit with Archaic period artifacts and features. Trenches 2,3 , and 4 showed a clear stratigraphy with cultural material found to a depth of about $1.5 \mathrm{~m}$. Ceramic sherds, as well as magnetite cobbles, were limited to the upper 30-40 cm (Strata I-II, see Figure 3). Stratum III had artifacts diagnostic of the Middle Archaic period Tom's Brook and Crystal Mountain phases (Schambach 1998) such as Johnson and Big Sandy dart points and notched pebble net sinkers, as well as quantities of novaculite chipping debris, biface and tool fragments, occasional ground stone tools/fragments, and pieces of burned and unburned sandstone and igneous rock. 


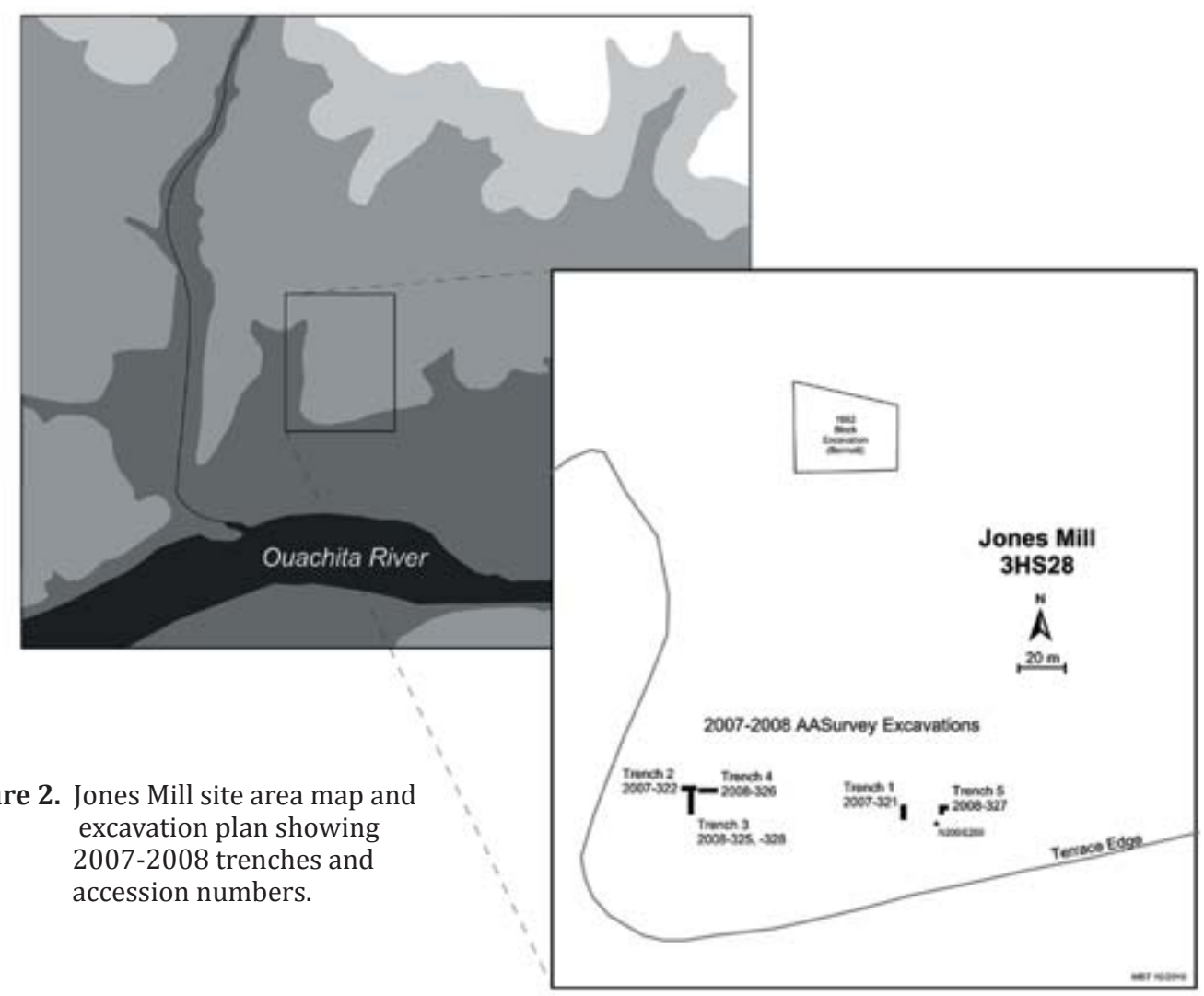

Figure 2. Jones Mill site area map and excavation plan showing 2007-2008 trenches and accession numbers.

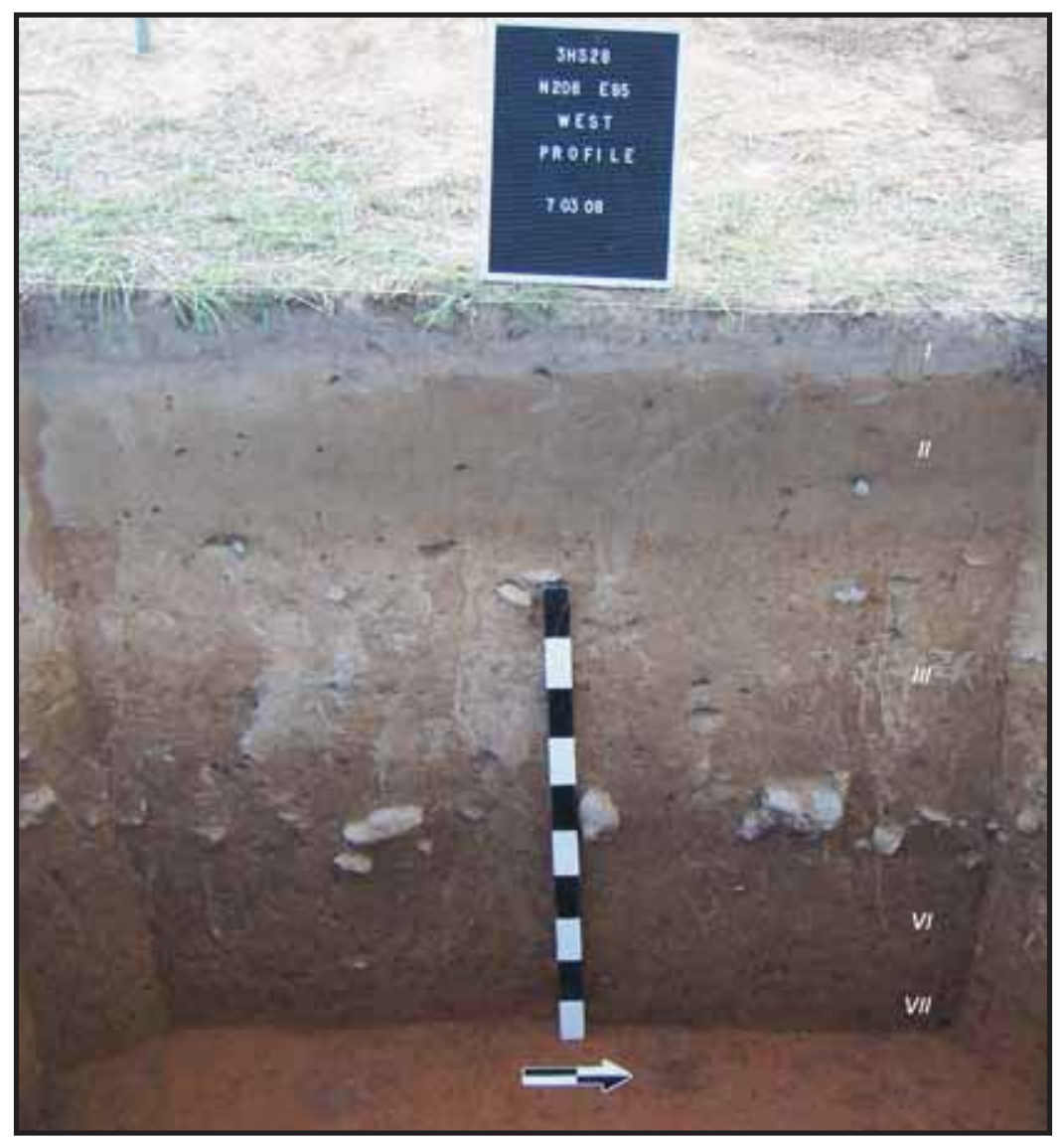

Figure 3. Profile of Trench 3 excavation at Jones Mill, Unit N206 E95, view west, showing Stratum I, II, III, VI, and VII (Stratum IV and V were not present in this area; photo AAS/HSU D_T4006). 
A discussion of dart points based on a sample from the 2008 excavations (Trubitt 2009a) highlighted metric differences and novaculite color preferences between the two general types (Johnson and Big Sandy or White River Side Notched). In a sample of 52 dart points, most (88\%) were broken, and many of these (48\%) showed distal impact fractures (Trubitt 2009a). Distal impact fractures are associated with use as projectiles (Johnson 1981; Titmus and Woods 1986). Many of these dart tips were broken through use- presumably in hunting-and refitted with new points at Jones Mill. This is indirect evidence for hunting. Other artifacts point to plant processing (fragments of sandstone grinding stones and pitted cobbles) and fishing or perhaps trapping small mammals or birds (notched pebble net weights or netsinkers). Currently, Dr. Melody Pope is examining a small sample of endscrapers from the site for microwear, and discussion of this evidence in terms of plant/animal/fish processing at the site will be covered in a future publication.

Many of the features found in the Middle Archaic Stratum III at Jones Mill were concentrations of rocks that included fire-cracked sandstone cobbles. These have been interpreted as refuse from hearths or fireplaces or from earth ovens or cooking pits. Especially in the millenia before the invention of pottery, people cooked with indirect heat, either heating rocks in a fire to use in "stone boiling" or using rock to hold the heat of the fire in earth ovens. These techniques resulted in quantities of burned and cracked rock discarded around cooking facilities, and explain the fire-cracked rock concentrations often found on Archaic period sites (see Hester 1991).

Radiocarbon dates have now been obtained on two of these burned rock features from Stratum III at Jones Mill, with funding from the Arkansas Archeological Society. The accelerator mass spectrometry technique was used to date small amounts of charred nutshell associated with these features from Trench 3. Feature 46, the deepest of these burned rock concentrations at about $1 \mathrm{~m}$ below ground surface, resulted in a conventional radiocarbon age of $7070 \pm 40$ BP, which calibrates to $6020-5880$ cal B.C. (2 sigma range, Beta254393, Trubitt 2009b). Feature 43, a small burned rock cluster at about $50 \mathrm{~cm}$ below surface, returned a conventional radiocarbon age of $5450 \pm 40$ BP, calibrated to 4350-4240 cal B.C. (2 sigma range, Beta-281374, Trubitt 2011). These dates give us an effective range for our Middle Archaic occupation of the Jones Mill site at 6000-4300 B.C.

Material associated with the features in Stratum III can give hints to their use. For example, Feature 46 had two notched pebble netsinkers as well as a Johnson type novaculite dart point. We are interested in learning whether cooking was done here and if so what was cooked. Dr. Mary Malainey has examined a small sample of fire-cracked rock fragments from the site for absorbed lipid residues. Her results and our interpretations of these features as Archaic cooking facilities will be the focus of a future publication. Charred plant remains from these features are also discussed later in this article.

The two trenches placed on the eastern side of the site uncovered better evidence of more recent occupations. Trench 1 and 5 had a thick dark brown organic midden deposit containing artifacts diagnostic of several time periods (Caddo, Woodland, Late and Middle Archaic). Several rock cluster features were excavated in Trench 1 in 2007 (Brock 2009). Features found in Trench 5 in 2008 included the bases of several postmolds (Figure 4). Based on analysis of materials incorporated into feature fill- especially the ceramics and botanical materials - as well as a new radiocarbon date, we can now interpret these as traces of a Caddo period building. If these posts are part of two opposite walls, it was a small building, since they are only about $3.5 \mathrm{~m}$ apart. Circular patterns of single-set posts between 4-16 $\mathrm{m}$ in diameter as well as square or rectangular patterns of posts with walls ranging from 3.8 to $8.8 \mathrm{~m}$ apart have been documented on Caddo period sites in west-central Arkansas (Trubitt 2009c). 


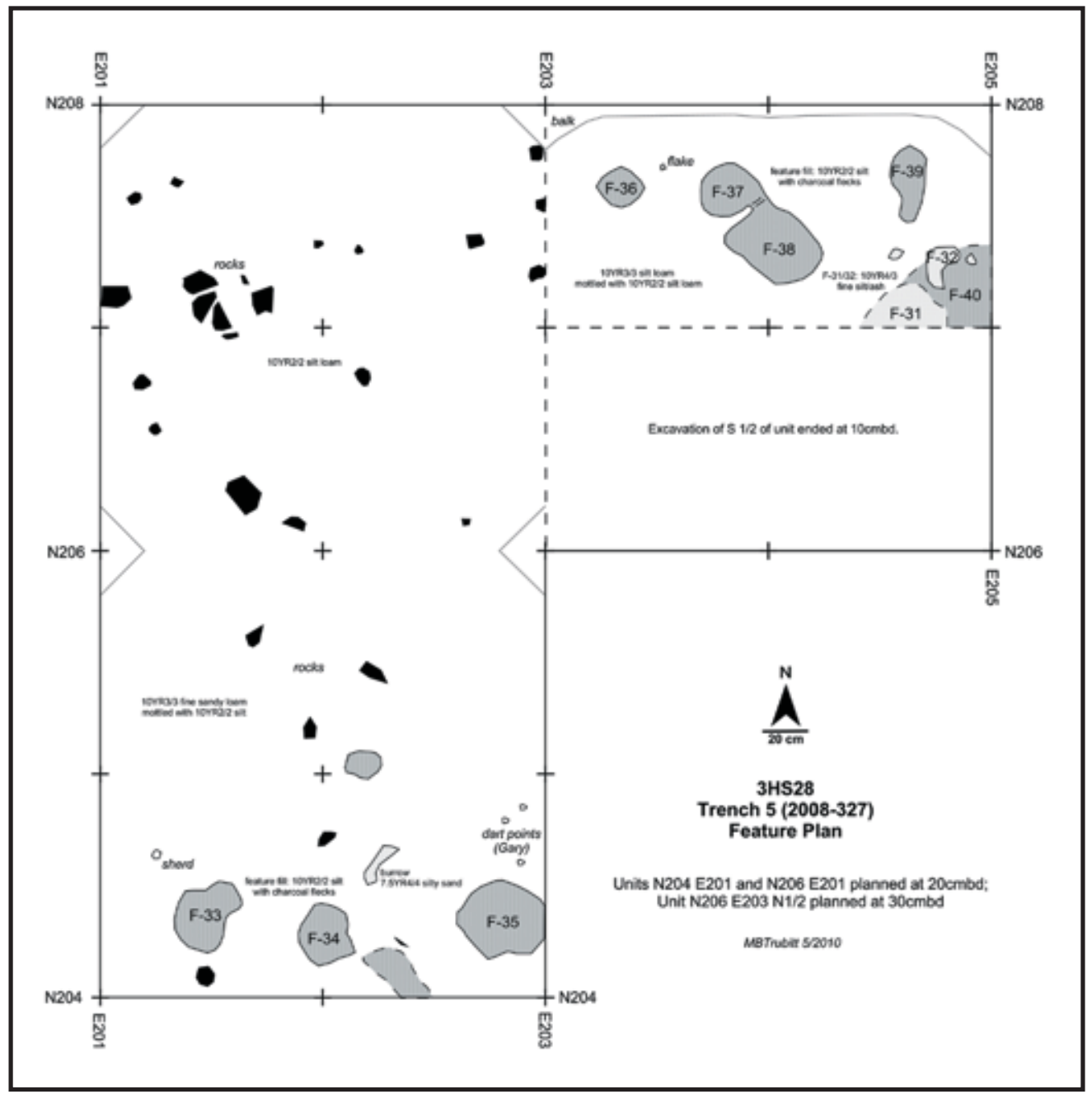

Figure 4. Feature plan for Trench 5 at Jones Mill.

With funds from the Arkansas Humanities Council, a new radiocarbon date was obtained from Jones Mill on a Trench 5 postmold (Feature 35) using the accelerator mass spectrometry technique. As discussed later in this paper, Parker identified maize from this feature, but the date was run on charred nutshell she identified as Carya (hickory). The AMS date returned a conventional radiocarbon age of $470 \pm 40 \mathrm{BP}$, calibrating to cal A.D. 1410-1460 (2 sigma range, Beta 282601, Table 1). Beta Analytic, Inc., reported an intercept of the radiocarbon age with the calibration curve (using INTCAL04) at cal A.D. 1440.

Table 1. New Radiocarbon Dating Results from Jones Mill (3HS28).

\begin{tabular}{|l|l|l|l|l|l|}
\hline $\begin{array}{l}\text { Sample ID } \\
\text { and Provenience }\end{array}$ & $\begin{array}{l}\text { Measured } \\
\text { Radiocarbon } \\
\text { Age Before } \\
\text { Present }\end{array}$ & $\begin{array}{l}\text { 13C/12C } \\
\text { Ratio }\end{array}$ & $\begin{array}{l}\text { Conventional } \\
\text { Radiocarbon } \\
\text { Age Before } \\
\text { Present }\end{array}$ & $\begin{array}{l}\text { Calibrated } \\
\text { Age, 1 sigma } \\
\text { range (68\% } \\
\text { probability) }\end{array}$ & $\begin{array}{l}\text { Calibrated } \\
\text { Age, 2 sigma } \\
\text { range (95\% } \\
\text { probability) }\end{array}$ \\
\hline $\begin{array}{l}\text { Beta-282601 } \\
\begin{array}{l}\text { 2008-327-33-9, } \\
\text { AMS charred } \\
\text { nutshell from F-35 }\end{array}\end{array}$ & $470 \pm 40 \mathrm{BP}$ & $-24.9 \mathrm{o} / \mathrm{oo}$ & $470 \pm 40 \mathrm{BP}$ & $\begin{array}{l}\mathrm{Cal} \mathrm{AD} \\
1420-1450\end{array}$ & $\begin{array}{l}\mathrm{Cal} \mathrm{AD} \\
1410-1460\end{array}$ \\
\hline
\end{tabular}


Trubitt's preliminary analysis of ceramic sherds from Trench 5 and the feature contexts found the majority tempered with grog or a grog-grit mixture, with shell, bone, and grit occurring in a minority of sherds. For Trench 5 as a whole ( $\mathrm{n}=221), 73 \%$ of the analyzed sherds were tempered with grog or a mixture of grog and grit and/or bone, $14 \%$ were tempered with shell or shell and grog, and 13\% were tempered with grit. For the Trench 5 features specifically $(\mathrm{n}=12), 83 \%$ were identified as grog or grog and grit tempered sherds and 17\% were identified as shell and grog tempered sherds. Shell tempering appears in Middle Ouachita River region ceramics during the Mid-Ouachita phase and has been dated to the late 1300s-early 1400s A.D. (see Early 2002; Perttula et al. n.d.). The minority presence of shell-tempering in Trench 5 and its features fits with the early-tomid 1400s A.D. date from Feature 35.

This article focuses on the results of specialized analyses by Parker (botanical materials) and Kelly (animal bone) to help interpret the foodways of the people who lived at Jones Mill. The key contexts to be discussed and contrasted here, therefore, are the Middle Archaic Stratum III in Trenches 2, 3, and 4 that includes burned rock features in Trench 3 dating to 6000-4300 B.C., and the Caddo period midden in Trench 5 that includes post features that were part of a building dating to A.D. 1440. The term 'foodways' refers to diet specifically, as well as to the ways social groups interacted with one another and with their environments to schedule food-getting activities throughout the year. Interpretation of site seasonality and duration of site occupation has repercussions for reconstructing the organization of novaculite tool production and access to nearby resources such as quarry sites.

\section{Methods of Analysis}

\section{Archaeobotanical Analysis}

Systematic flotation sampling of excavated cultural features provided essential baseline data about plant use patterns during prehistoric occupations at the Jones Mill site widely separated in time. All feature matrix samples from the site were processed by water flotation. A de-flocculent (baking soda) was typically added to facilitate dispersion of charred plant material from soil matrix (Pearsall 1989). In addition, the heavy fractions from two samples were reprocessed using a sugar water solution according to methodology suggested by Dr. Tristram Kidder (1997). Because sugar water has a higher specific gravity than water alone, charred plant remains are more prone to float rather than settle into heavy fractions. There was no discernable difference in botanical recovery from the two Middle Archaic samples tested, but the result may have been determined by the predominance of relatively dense nutshell, and absence or scarcity of all other classes of botanical material.

All processed and dried flotation samples received by Parker for analysis were sorted into two particle sizes with the aid of a No.10 geological sieve (2 mm mesh). Using a standard binocular microscope at low magnification (7-10x), all carbonized materials (wood, nutshell, seed, etc.) retained by the screen ( $>2 \mathrm{~mm}$ ) were extracted, weighed and counted, and an attempt made to identify all plant materials other than wood. Nutshell and wood counts and weights are based on materials in this large size fraction only.

Identification of the first 20 randomly selected wood fragments was attempted (or all wood, if there were less than 20) for the large fraction of each sample. In this analysis, charred wood fragments examined but found to be unidentifiable at least to family were grouped into one of five categories: gymnosperm, ring porous hardwood, diffuse porous hardwood, bark or unidentifiable. Gymnosperm wood in this region of Arkansas could be from shortleaf pine (Pinus echinata) or Eastern red cedar (Juniperus virginiana). Ring porous woods may be from any one of several commonly occurring deciduous trees including various oaks (Quercus sp.), hickory (Carya sp.) and ash (Fraxinus sp.). Diffuse porous tree taxa include trees such as poplar/cottonwood (Populus sp.) and boxelder/maple (Acer sp.). Bark consists of small, thin, non-distinctive fragments. Wood 
fragments in which all distinctive morphological traits were distorted or destroyed during carbonization were classified as unidentifiable.

The small fraction ( $<2 \mathrm{~mm}$ ) of each sample was examined carefully using a 10-30x binocular microscope in order to recover seeds, grass stems, maize (Zea mays) fragments and any other non-wood or nutshell items. Any of these items were extracted and identified if possible.

In addition to botanical remains from flotation, four water-screened samples from various levels of a single Trench 5 excavation unit were analyzed to provide a comparison between midden and features. Materials were sorted into the same categories (wood, nutshell, maize) used for flotation samples.

Seed, nut and wood identifications for both the flotation and water-screened remains were based on morphological characteristics, with reference to modern comparative specimens and standard pictorial guides (e.g. Martin and Barkley 1961; Hoadley 1990). All identifications were carried to the lowest possible taxon, usually to the genus level. Species identifications were attempted only when morphological comparisons ruled out other members of a genus (i.e. Polygonum erectum). Scientific nomenclature and general floristics information follows the USDA plants database (USDA 2010).

Zooarchaeological Analysis: All bone was processed in the Arkansas Archeological Survey's HSU Research Station lab before a sample was sent to Kelly for analysis. Bone was recovered using three methods: hand-collected (including $1 / 4$ " screen) during general excavation, water-screened through $1 / 16$ " window mesh, and picked from the heavy fraction of processed flotation samples taken from features. All bone in this study was identified by direct comparison to modern osteological collections belonging either to Kelly or housed at the Illinois State Museum Records and Research Facility in Springfield, Illinois. Dr. Robert Warren of the Illinois State Museum very kindly identified the mussel shells. The faunal remains were analyzed and tabulated separately by recovery method. Flotation and water-screening facilitates the recovery of smaller bones and greater quantities of bone.

Identification of the faunal remains was made to the most specific taxonomic level possible, given the completeness and portion of the bone present. Nomenclature for mammals follows Hoffmeister (1989); for birds, Bohlen (1989); for fish, Pflieger (1975); for reptiles, Johnson (1992) and Cummings and Mayer (1992) for freshwater mussels. Taxonomic names, however, were verified through the Integrated Taxonomic Information System website (ITIS 2010) and in some cases were changed to the most up-to-date usage. Some elements from the same animal are more diagnostic than others (Driver 1992; Reitz and Wing 2008). Therefore, not all elements can be identified with equal certainty or specificity. If a bone could be only tentatively identified to a certain taxon, then the taxon was given a "cf." designation. Tentatively identified bones were combined with bones that could be more definitively identified as that taxon when listed in the summary tables. If there were no other bones that could be definitively identified, then the "cf." designation was retained in the tables.

As is common in zooarchaeology (Driver 1992; Reitz and Wing 2008; Uerpmann 1973), when a mammal or bird bone could not be identified to a taxon more specific than class, it was placed in a size category where possible. Table 2 provides the key to the animal size categories constructed. The categories of large, medium, and small are based on the size of the major bones in a skeleton. The intermediary categories of largemedium and medium-small in the summary tables are catch-all categories. For example, the category largemedium includes bone fragments that could belong to an animal of medium, medium to large, or large size. The bones are usually small fragments for which element cannot be determined. Placing bones in the intermediary categories is very subjective, therefore these categories do not have much analytic value beyond identifying indeterminate bone fragments within a class to a slightly finer level than simply "indeterminate." 
Table 2. Faunal Size Classes.

\begin{tabular}{|c|c|}
\hline Size Class & Animals Falling within Size Class \\
\hline Large Mammal & Deer, Bear \\
\hline Medium Mammal & Raccoon, Rabbit, Muskrat, Squirrel \\
\hline Small Mammal & Mouse, Vole, Mole \\
\hline
\end{tabular}

For each bone identifiable to the level of class or to a more specific taxon, the following information, when applicable, was recorded: faunal catalogue number, complete provenience information, recovery technique (general excavation, flotation, or water-screen), taxonomic identification, element name, side, portion present, percent complete, epiphyseal fusion, tooth wear and eruption, modification, placement of modification, number of fragments, and weight. Additional information and observations were entered into a comments section, if necessary. Types of modifications recorded include weathering, gnaw marks, cut marks, staining, and burning. For the deer bone, locations of cut marks were recorded to possibly aid interpretation of butchery techniques.

Where possible for deer remains, epiphyseal fusion and tooth eruption and wear were recorded. Relative age of deer can be calculated from these characteristics (Gilbert 1990; Purdue 1983; Reitz and Wing 2008; Severinghaus 1949). Epiphyseal fusion and tooth wear do not give as accurate an age as tooth eruption, but general age categories can be constructed (Purdue 1983; Reitz and Wing 2008). All three aging methods are subject to individual variation in health, diet, and environment and-for fusion - the sex of the animal.

There has been much discussion over the years about the use of the basic quantification measures in zooarchaeology: NISP (number of identifiable specimens) vs. the use of MNI (minimum number of individuals) (for example, Chaplin 1971; Gautier 1984; Grayson 1984; Klein and Cruz-Uribe 1984; Marshall and Pilgram 1993). The use of either NISP or MNI has its drawbacks and can be affected by intensity of fragmentation and sample size. To partially offset the problems associated with these measures, both NISP and MNI, when applicable, are used here for the taxa identified. For NISP, if two or more fragments could be glued or fitted together, they were counted as one. This rule also applies to unfused epiphyses that could be refitted to their shafts.

MNI was figured by excavation trench (Trench 5 only) for each species by counting the most frequently occurring element after dividing it into lefts and rights (if applicable). Completeness, portion, age, and, in some cases, size were taken into consideration. MNI was also calculated for family and genus levels if no species within the family or genus had been identified for the unit. Or, if species were identified within a family or genus, MNI was calculated for that genus and/or family only after the MNI had been calculated for the species, and hence is exclusive of the species MNI count. MNI was not figured for the class or order levels.

Some weathering, carnivore and rodent gnawing, and staining have taken place indicating bones in some areas were exposed to the elements. A portion of the assemblage has been burned. In some cases, only singeing is evident and that may reflect a cooking method such as roasting, where only a small part of exposed bone was directly subjected to fire. More calcined bone than singed or charred bone was recovered (Table 3). This may indicate the bone was included in fire as part of trash disposal where it would have been subjected to high heat or prolonged exposure. 
Table 3. Summary of Burning for Faunal Remains (NISP) from Jones Mill (3HS28).

\begin{tabular}{|c|c|c|c|c|c|c|c|c|}
\hline & \multicolumn{4}{|c|}{$\begin{array}{l}\text { Trench } 3 \text { and } 4 \\
325+328,326\end{array}$} & \multicolumn{4}{|c|}{$\begin{array}{c}\text { Trench } 5 \\
327\end{array}$} \\
\hline & calcined & black & unburn & wt. $g$ & calcined & black & unburn & $w t . g$ \\
\hline mammals & & & & & 84 & 22 & 366 & 353.6 \\
\hline birds & & & & & & & 1 & 1.0 \\
\hline fish & & & & & & & 20 & 0.5 \\
\hline reptiles & & & & & 10 & 3 & 29 & 16.2 \\
\hline amphibians & & & & & & & 2 & 0.1 \\
\hline indeterminate vertebrate & 15 & & & 1.6 & 388 & 32 & 502 & 129.2 \\
\hline invertebrates & & & 1 & 0.4 & & 2 & 512 & 269.6 \\
\hline Total & 15 & 0 & 1 & 2.0 & 482 & 59 & 1432 & 770.2 \\
\hline
\end{tabular}

\section{Middle Archaic Foodways}

\section{Archaeobotanical Analysis}

Thirteen flotation samples totaling 174 liters of soil matrix collected from distinct cultural deposits in Trench 3, usually clusters of fire-cracked and natural rock and artifacts and charcoal defined as features, made up the Archaic sample. Carbonized macrobotanical remains in the Trench 3, Stratum III, flotation samples consisted of 670 nutshell and wood fragments having a combined weight of $8.9 \mathrm{~g}$ (Table 4). The resulting mean botanical density was $0.06 \mathrm{~g} /$ liter, low but also typical for an early prehistoric component. Nutshell from Feature 11, a cluster of magnetite cobbles at the top of Stratum II that post-dates the Middle Archaic component, was excluded from these calculations.

Nutshell was recovered from every sampled provenience in Trench 3, and was by far the dominant category of plant material, totaling 643 fragments ( 8.5 g). Thick-shelled hickory (Carya sp.) comprised 92\% of all nutshells in this assemblage, the remaining $8 \%$ consisting of eroded, amorphous, thick pieces assignable only to the hickory/walnut family (Juglandaceae). A flotation sample from another Middle Archaic feature (F4) in Trench 2, previously analyzed by Dr. Kitty Roberts, disclosed a similar combination of eroded hickory/ walnut shell and hickory (Trubitt 2009a). Hickory/walnut fragments from the Archaic component are assumed to be entirely hickory rather than including black walnut or butternut, since no remains of these latter species have been present in any of the analyzed Jones Mill samples.

The Trench 3 wood assemblage was comprised of extremely small fragments that sometimes appeared twisted or torqued, with resulting morphology that was distorted and unidentifiable. Eight of thirteen flotation samples yielded wood fragments. In the 42 fragments recovered (total $0.6 \mathrm{~g}$ ), only ten could be identified, representing four deciduous tree taxa including oak (both Quercus sp. and red oak subgroup, $Q$. sp., subgenus Erythrobalanus), Osage orange (Maclura pomifera), hickory (Carya sp.) and hackberry/sugarberry (Celtis sp.).

The combination of plant resources indicated in Jones Mill Archaic deposits, consisting of an abundant, edible and highly nutritious nut mast (hickory), and high quality fuel woods (oak, hickory, hackberry/sugarberry, and Osage orange) typifies Middle Archaic archaeobotanical recovery patterns in the Eastern Woodlands (cf. Asch and Asch 1985; Simon and Parker 2006; Stafford 1991). The Osage orange wood in the Middle Archaic sample may have been an import, if it was geographically restricted to an area of Blackland Prairie in East Texas between the end of the Pleistocene and initial European contact, as argued by Schambach (2003) (but see Early 2000) . The widespread and predictable high frequency of hickory nutshell recovered from Middle Archaic components suggests that harvest of mast resources was, even at this early time, a long and well-established focus of subsistence strategies. 


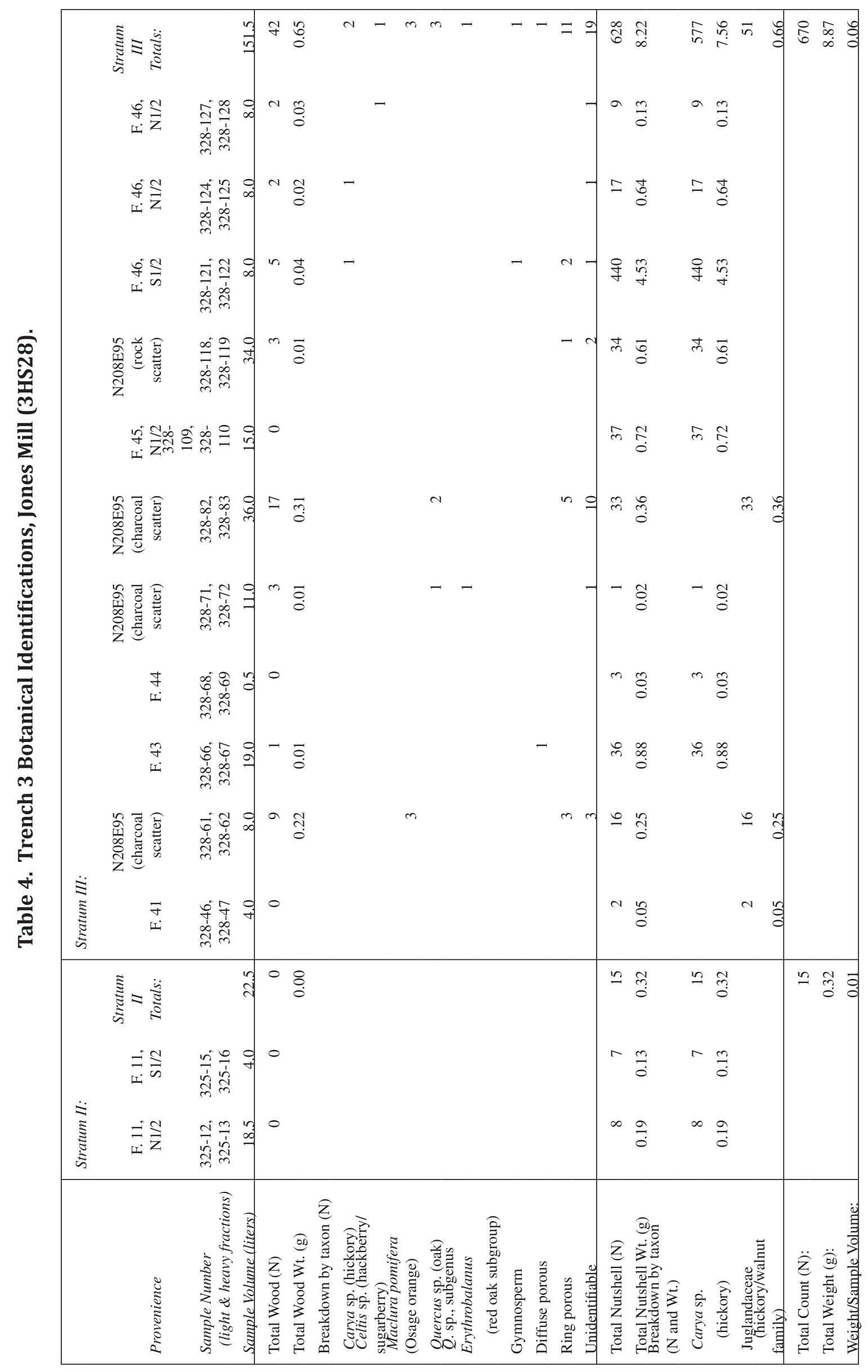




\section{Zooarchaeological Analysis}

Fragments of animal bone and shell collected from the Trench 3 and 4 excavations formed the Archaic sample examined from Jones Mill. Unfortunately, no faunal remains could be identified from these trenches (Table 5). The remains present consist of primarily small fragments of calcined bone that do not retain any distinguishing characteristics allowing for identification even to the class level. One small fragment of a freshwater mussel shell was recovered from Trench 3 (Accession 2008-328). It is therefore not possible to comment on the faunal subsistence of the Archaic inhabitants that could give insight into questions concerning the seasonality of occupation at the Jones Mill site or movement of Archaic populations at this time. Elsewhere in the area Archaic populations were hunters, gatherers, and fishers who exploited a variety of wild plants and animals for food (Jackson and Scott 2001).

Table 5. Summary of Faunal Remains (NISP) from Trenches 3 and 4, Jones Mill (3HS28).

\begin{tabular}{|l|rrr|r|rr|r|}
\hline & \multicolumn{4}{c|}{ Trench 3} & \multicolumn{3}{c|}{ Trench 4 } \\
\cline { 2 - 8 } & ws & gen. ex. & ws & Total & gen. ex & ws & Total \\
& 325 & 328 & 328 & & 326 & 326 & \\
\hline Indeterminate Vertebrate & 4 & 3 & 5 & 12 & 1 & 2 & 3 \\
Invertebrate (Unionidae) & 4 & 4 & 5 & 13 & 1 & 2 & 3 \\
\hline Total & & 4 & & & & & 3 \\
\hline
\end{tabular}

\section{Caddo Foodways}

\section{Archaeobotanical Analysis}

Charred macrobotanical remains from flotation sampling of eleven cultural features encountered in Trench 5 formed the Caddo period sample, and consisted primarily of nutshell, wood and maize (Table 6). Seeds were comparatively sparse but included Eastern Complex (EC) starchy cultigens. Four water-screened samples from 0 through $40 \mathrm{~cm}$ below surface in one unit contributed a similar range of botanical materials: hickory nutshell, wood and maize, but not seeds (Table 7). All of the features sampled are variously sized postmolds with plant remains that suggest domestic refuse from nearby processing or use activities. The 85 liters of soil in flotation samples produced $28.6 \mathrm{~g}$ of carbonized wood and nutshell ( 1676 fragments $>2 \mathrm{~mm}$ in size), equivalent to a mean density of $0.34 \mathrm{~g}$ / liter, or by fragment count 19.8 / liter. All analyzed samples contained identifiable nutshell and wood, but nutshell fragment counts were approximately twice those of wood. The presence of small amounts of maize in a majority of samples strongly suggested a post A.D. 850 Caddo affiliation for Trench 5 features (Perttula 2008). The AMS date that was run on Feature 35 confirmed the Caddo association.

At least eight tree taxa were represented in 109 wood fragments identified, out of 177 examined in a total of 503 fragments recovered (Table 8). Oak, including a few fragments from the red and white subgroups (Q. sp., subgenera Erythrobalanus and Lepidobalanus), together with hickory comprised nearly $70 \%$ of the identified wood, followed in descending order by shortleaf pine (Pinus echinata), Eastern red cedar Uuniperus virginiana), hackberry/sugarberry, sycamore (Platanus occidentalis), Osage orange and elm family (Ulmaceae). Oak and pine were each present in the majority of flotation samples, followed in ubiquity by hickory and red cedar. Several wood fragments in water-screened samples from levels 2 and 3 of Trench 5 were identifiable as hickory, pine and oak. Together the quantitative data suggest that four upland forest taxa: oak, hickory, pine and red cedar, provided most of the fuel used by Caddo residents at the site. 


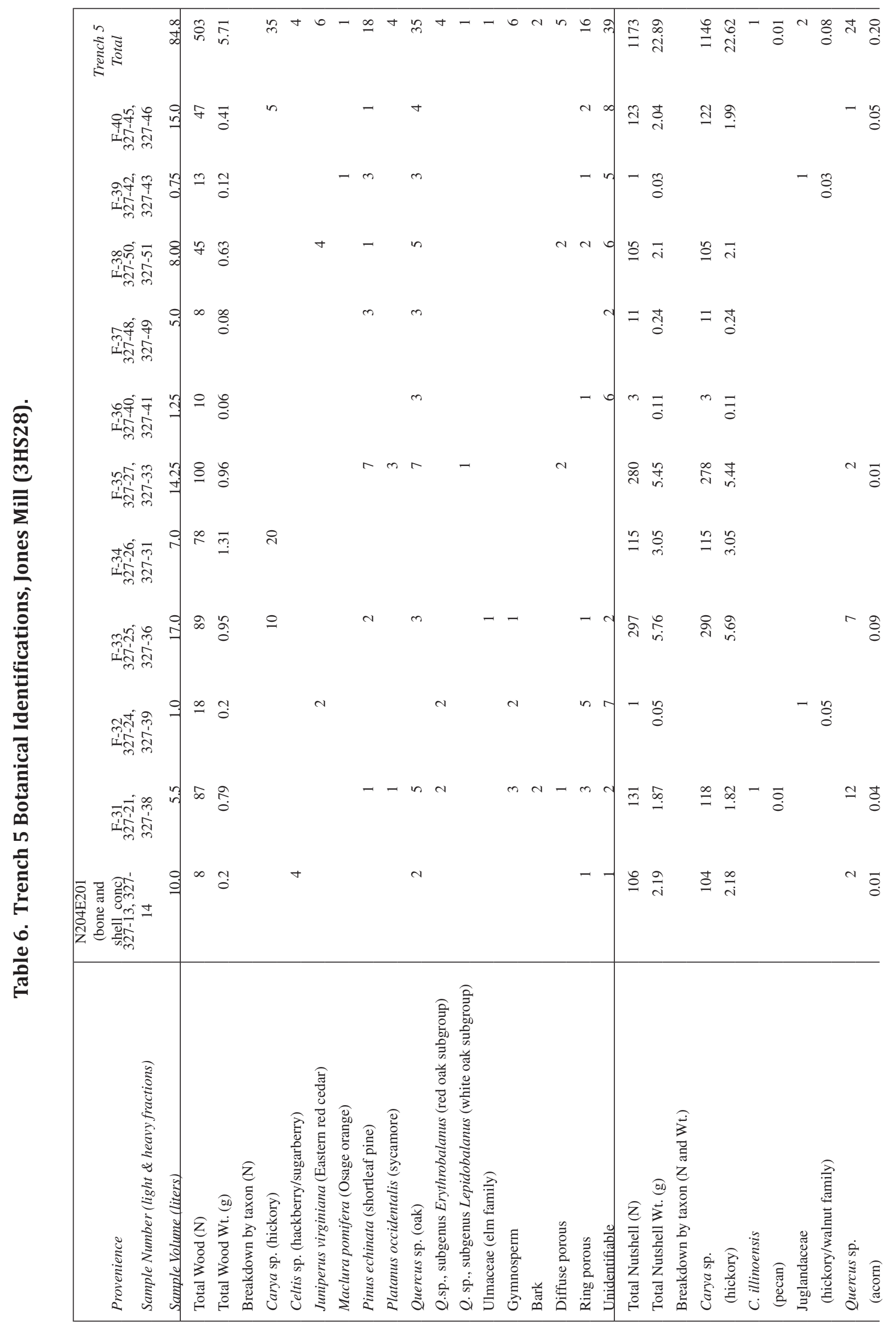




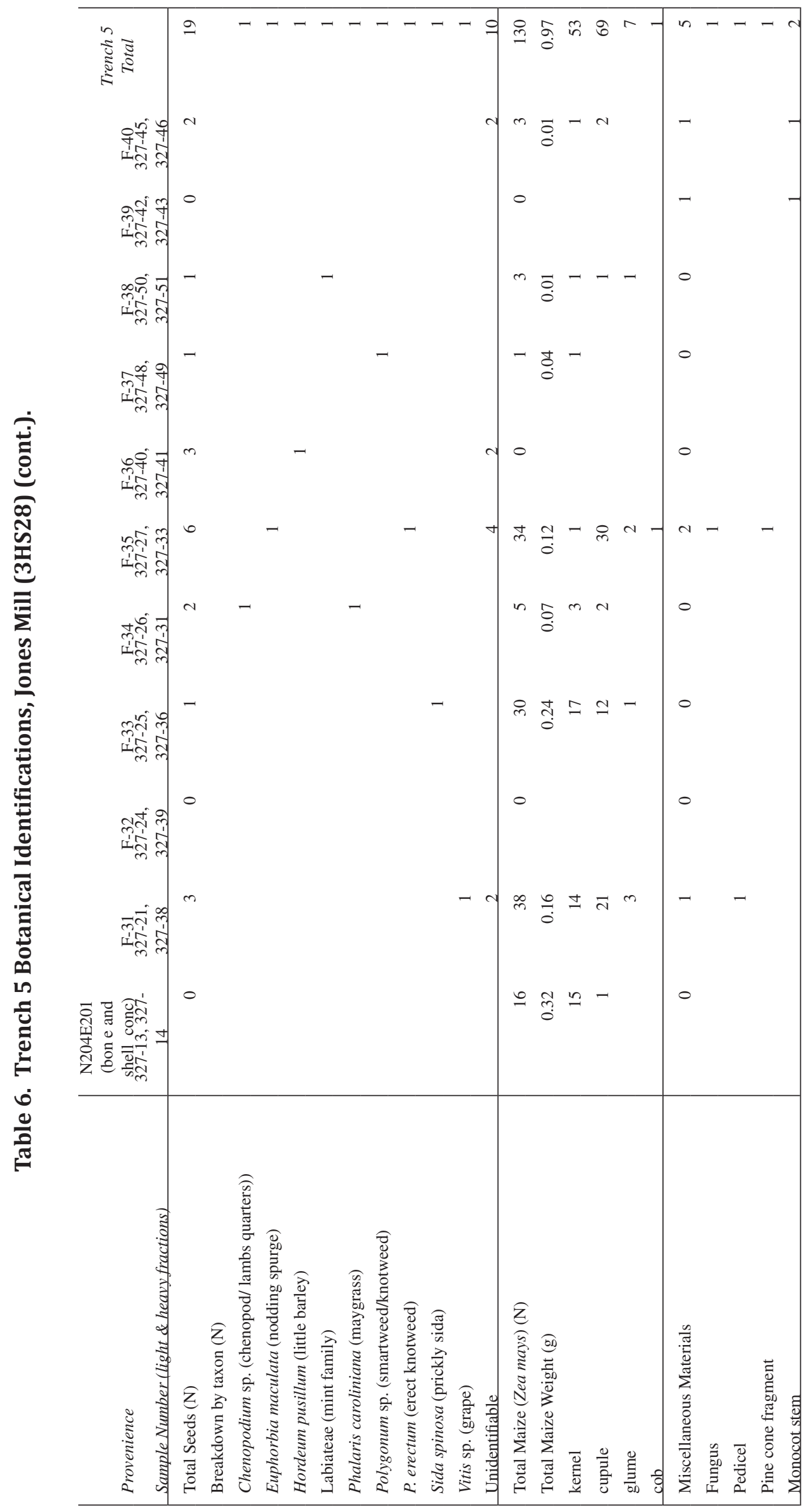


Table 7. Listing of Identified Botanical Materials from Trench 5 Waterscreened Column.

\begin{tabular}{|l|l|l|r|}
\hline Sample No & $\begin{array}{c}\text { N206E201 } \\
\text { Level }\end{array}$ & Type of Material Identified & $\begin{array}{r}\text { Weight } \\
(\mathrm{g})\end{array}$ \\
\hline $2008-327-3$ & $0-10 \mathrm{~cm}$ & 6 hickory nutshell fragments & 0.14 \\
\hline $2008-327-9$ & $10-20 \mathrm{~cm}$ & 24 hickory nutshell fragments & 0.60 \\
& & 7 wood fragments (hickory, pine and indeterminate diffuse porous) & 0.16 \\
& & 2 maize cupules (1 measurable =6.0 x 3.5 \{ LxW in $\mathrm{mm}\}, 45$ degree angle & 0.03 \\
\hline $2008-327-19$ & $20-30 \mathrm{~cm}$ & 21 hickory nutshell & 0.63 \\
& & 3 wood fragments (pine and oak) & 0.02 \\
& & 4 maize cupules and 1 cob fragment & 0.06 \\
\hline $2008-327-29$ & $30-40 \mathrm{~cm}$ & 23 hickory nutshell fragments & 0.50 \\
& & 1 maize cob fragment & 0.01 \\
\hline
\end{tabular}

Table 8. Wood Identifications from Trench 5.

\begin{tabular}{|c|c|c|c|}
\hline Wood Type & $\begin{array}{l}\text { Number of } \\
\text { Fragments }\end{array}$ & Percentage & $\begin{array}{c}\text { Feature } \\
\text { Ubiquity }\end{array}$ \\
\hline Carya sp. (hickory) & 35 & $32.11 \%$ & $27.3 \%$ \\
\hline Celtis sp. (hackberry/sugarberry) & 4 & $3.67 \%$ & $9.1 \%$ \\
\hline Juniperus virginiana (Eastern red cedar) & 6 & $5.50 \%$ & $18.2 \%$ \\
\hline Maclura pomifera (Osage orange) & 1 & $0.92 \%$ & $9.1 \%$ \\
\hline Pinus echinata (shortleaf pine) & 18 & $16.51 \%$ & $63.6 \%$ \\
\hline Platanus occidentalis (sycamore) & 4 & $3.67 \%$ & $18.2 \%$ \\
\hline Quercus sp. (oak) & 35 & $32.11 \%$ & $81.8 \%$ \\
\hline Q. sp., subgenus Erythrobalanus (red oak subgroup) & 4 & $3.67 \%$ & $18.2 \%$ \\
\hline Q. sp., subgenus Lepidobalanus (white oak subgroup) & 1 & $0.92 \%$ & $9.1 \%$ \\
\hline Ulmaceae (elm family) & 1 & $0.92 \%$ & $9.1 \%$ \\
\hline Total & 109 & $100.00 \%$ & \\
\hline
\end{tabular}

Similar to the botanical assemblage from Trench 3, flotation-derived nutshell was predominantly thickshelled hickory, accounting for approximately $98 \%$ of all fragments. However, taxonomic diversity was slightly higher in this component, with small amounts of acorn (Quercus sp.), and traces (one or two fragments each) of pecan (C. illinoensis) and eroded amorphous hickory/walnut family. Several samples had fairly high nutshell counts numbering more than 100 hickory fragments, occasionally accompanied by a few pieces of acorn. In addition to thick nutshell processing refuse subsequently used as fuel, one fragmentary acorn cotyledon from Feature 40 represents an edible product that may have been lost in parching or some other form of pre-storage processing. All four water-screened samples had hickory nutshell but no other mast remains. While foraging strategies clearly targeted hickories, it is possible that acorn was more economically important than can be inferred from low nutshell frequency in Jones Mill and other prehistoric assemblages. When exposed to fire, thin acorn shells would often have been totally consumed, in comparison to the thick, dense shell of nuts in the Juglandaceae group, which are more likely to survive burning. 
Among the 19 seeds recovered from Trench 5 samples, only nine could be identified, each representing a different plant taxon. Thus the assemblage is best described as diverse taxonomically, but also highly diffuse, meaning very low frequencies of any single seed type. Seeds of economic resources included one each of the EC starchy cultigens, little barley (Hordeum pusillum), erect knotweed (Polygonum erectum) and maygrass (Phalaris caroliniana). The erect knotweed specimen from Feature 35 typifies one of two recognized achene morphs, characterized by a slender, elongate form and a smooth, paper-thin pericarp. The second morph, not represented here, is squat and terete in form with thick punctate pericarps. Both types can occur on the same plant, but the proportion of elongate, thin pericarp morphs increases late in the harvest season. One partial chenopod (Chenopodium sp.) seed had a coating of soil that obscured surface morphology and seed margins. It is therefore unclear whether this specimen represents wild or cultivated $C$. berlandieri, or an entirely different species. In the context of Features 34, 35 and 36, which had seeds of three other EC starchy cultigens and/or maize, recovery of a C. berlandieri cultigen would not be unexpected, however.

A grape (Vitis sp.) seed from Feature 31 reflects availability of a wild edible fleshy fruit. Grape seeds are one of several sweet or sour fleshy fruits represented in prehistoric assemblages of all time periods from the Archaic onward and presumably universally harvested. Seeds of wild herbaceous plants that would have occurred naturally in the Jones Mill site vicinity included nodding spurge (Euphorbia maculata), mint family (Labiateae), smartweed/knotweed (Polygonum sp.) and prickly sida (Sida spinosa). Collectively, spurge, smartweed/knotweed and sida constitute a group of weedy taxa that would have found favorable growing conditions in fields, gardens and other areas disturbed by frequent human activity. Spurge and mint may have had medicinal uses (Williams 2000a).

Maize was recovered from 8 of 11 features (73\%), a sample ubiquity typical of late prehistoric components in many areas of the Eastern Woodlands and Plains regions, including Caddo sites in the Ouachita River basin (Perttula 2008). The maize fragment count of 130 (1.0 g) from Trench 5 samples is low, however, equivalent to a mean of 1.5 fragments/ liter of processed sediment. Maize was similarly scant in waterscreened samples, totaling seven cupule and cob fragments. Inedible parts of the ear including cupule, glume and cob fragments slightly outnumbered those of edible kernels, but both types of remains co-occurred in most samples with maize, suggesting harvest and use of a locally grown crop. One cupule recovered through water screening was sufficiently intact to measure, having width $\mathrm{x}$ height in $\mathrm{mm}$ of $6.0 \times 3.5$, and an angle of 45 degrees. Interpretations of row number based on single cupules are regarded as unreliable, but tentatively this specimen suggests an ear with 16 rows of kernels.

Items in the category of miscellaneous materials numbered five, subsuming monocot stem, fungal tissue, pedicel (flower stalk), and pine cone fragment. This limited array of materials is tentatively interpreted as kindling and/or incidental vegetation debris that fell or blew into space around posts. 


\section{Zooarchaeological Analysis}

Animal bone and shell from Trench 5 excavations on the eastern side of the site made up the Caddo period sample. Trench 5 yielded a total of 1459 vertebrate and 514 invertebrate remains (Table 9). Most of the remains came from dry or water-screened samples from the midden; all the fauna recovered from features was from flotation samples (Table 10). While preservation was better on this side of the site, it still was not optimal. It is assumed the inhabitants utilized a larger range of animals than is indicated by the identified remains. Of the vertebrate remains $42 \%$ were calcined and another $4 \%$ were burned black or charred. Therefore the majority is unburned (Table 3). A large percent (63\%) could not be identified to the class level, but this is substantially better than the $100 \%$ of the remains from Trenches 3 and 4 that were unidentifiable. Of the invertebrate remains, only $4 \%$ could be identified to more a specific taxon than freshwater mussel (Unionidae) or gastropod (Gastropoda). Three taxa of mammals, 1 of birds, 3 of fish, 3 of reptile, and 1 of amphibian were identified. Five taxa of freshwater mussel were identified. All but one of the 20 fish remains were recovered from flotation.

Deer remains were the most numerous in the mammalian class. Two other taxa were identified, tree squirrel (Sciurus sp.) and possible a skunk (Mephitis mephitis), but are represented by only 1 specimen each. The possible skunk is represented from a stained mandibular molar and is a very tentative identification. The archaeological specimen is larger than the comparative specimens available.

The deer remains are primarily specimens that are of higher density, and thus stood a better chance of survival. Table 11 lists the deer specimens recovered. Elements from the extremities were present in a higher percentage than what would be expected in a single deer. Axial elements, which are usually less dense, are present in a much lower percentage. Two individuals may be represented based on two complete mandibular $4^{\text {th }}$ premolars. One is an adult tooth and the other is a deciduous tooth. Because the teeth are not in mandibles, it is possible they could be from a single individual that was in the process of shedding its deciduous dentition and the permanent premolar was erupting. The deciduous premolar, however, has no sign of wear and the adult premolar has moderate wear. This is the opposite of what would be expected in the scenario just given, therefore two individuals are identified. Because the teeth are not in mandibles it is more difficult to assign an age based on tooth eruption or even wear. Deer lose their deciduous dentition at around $1 \frac{1}{2}$ years of age. Therefore, one of the deer represented is over $1 \frac{1}{2}$ years and the other is younger (Schwartz and Schwartz 1981; Gilbert 1990).

Epiphyseal fusion was observable on only three bones, but supports the tooth eruption ages. An unfused distal tibia would come from an individual that was less than 17 months. The fused $1^{\text {st }}$ phalanx and fused distal metapodial would come from an individual older than 17-29 months (Purdue 1983).

A first phalanx exhibits cut marks across its distal end. This was the only deer remain with cut marks. A couple of large and medium-large mammal fragments, which are quite possibly deer, also had cut marks.

Only one bird taxon, a turkey (cf. Meleagris gallopavo) could be identified and it is somewhat tenuous because of the fragmentary condition of the specimen. No other bone fragments could be identified to the Avian class level.

Three fish taxa were identified, all but one came from flotation of feature fill (Table 10). The lone fish remain from excavation was an Ictalurid (catfish family). From flotation the remains represent the sunfish (Centrarchidae) family with one more specifically identified to the sunfish genus (Lepomis). Without being able to identify the species of fish present, it is difficult to determine the aquatic habitat that was being exploited, however, it would most likely be the adjacent Ouachita River.

\section{8 - Volume 21, 2011}


Turtles were exploited to some degree. Most remains are small indeterminate fragments of carapace or plastron. Softshell turtle (Apalone sp.) could be identified because of its distinctive textured shell. Box turtle (Terrepene sp.) was also identified. Two amphibian remains are present.

Table 9. Summary of Animal Taxa from Trench 5, Jones Mill (3HS28).

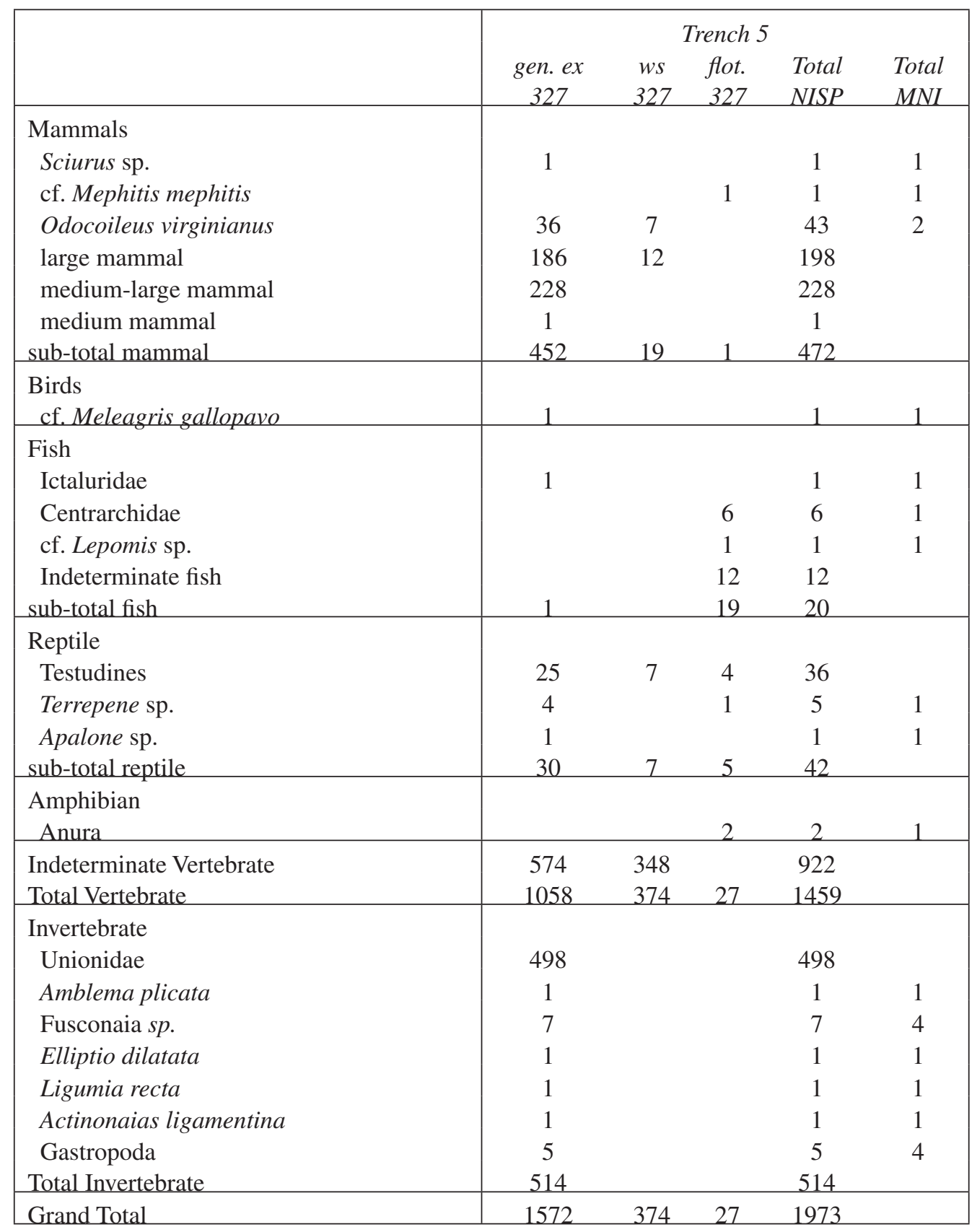


Table 10. Summary of Faunal Remains (NISP) from Features in Trench 5 (Flotation).

\begin{tabular}{|c|c|c|c|c|c|c|c|}
\hline & \multicolumn{7}{|c|}{ Trench 5} \\
\hline & $F-31$ & $F-33$ & $F-35$ & $F-37$ & $F-38$ & $F-40$ & Total \\
\hline $\begin{array}{l}\text { Mammals } \\
\text { cf. Mephitis mephitis } \\
\text { sub-total mammal }\end{array}$ & & & & 1 & & & 1 \\
\hline Fish & & & & & & & \\
\hline Centrarchidae & 1 & 2 & 3 & & & & 6 \\
\hline cf. Lepomis sp. & & & & & 1 & & 1 \\
\hline Indeterminate fish & & 2 & 6 & & 2 & 2 & 12 \\
\hline sub-total fish & 1 & 4 & 9 & & 3 & 2 & 19 \\
\hline Reptile & & & & & & & \\
\hline Testudines & & 2 & & & & 2 & 4 \\
\hline Terrepene sp. & & & & 1 & & & 1 \\
\hline sub-total reptile & & 2 & & 1 & & 2 & 5 \\
\hline $\begin{array}{l}\text { Amphibian } \\
\text { Anura }\end{array}$ & & & & & 2 & & 2 \\
\hline Total Vertebrate & 1 & 6 & 9 & 2 & 5 & 4 & 27 \\
\hline
\end{tabular}

Table 11. List of Deer Elements (NISP) Recovered from Trench 5.

\begin{tabular}{|c|c|c|c|c|c|}
\hline Extemities & Standard & Trench 5 & Axial & Standard & Trench 5 \\
\hline Antler & 2 & 1 & Innominate & 2 & \\
\hline Astragalus & 2 & 2 & Rib & 26 & 2 \\
\hline Atlas & 1 & & Sacrum & 1 & \\
\hline Axis & 1 & & Scapula & 2 & \\
\hline Calcaneum & 2 & 1 & Sternebra & 7 & \\
\hline Cuboid & 2 & 1 & Vertebra, cervical & 5 & 2 \\
\hline Greater Cuneiform & 2 & 2 & Vertebra, thoracic & 13 & 1 \\
\hline Hyoid & 2 & & Vertebra, lumbar & 6 & \\
\hline Lateral maleolus & 2 & & Total & 62 & 5 \\
\hline Lesser Cuneiform & 2 & & $\%$ & $28.60 \%$ & $12.80 \%$ \\
\hline Lunate & 2 & & & & \\
\hline Magnum & 2 & 1 & Appendicular & & \\
\hline Mandible & 2 & & Humerus & 2 & 1 \\
\hline Metacarpal & 2 & & Radius & 2 & \\
\hline Metacarpal, vestigial & 4 & & Ulna & 2 & \\
\hline Metatarsal & 2 & 2 & Femur & 2 & \\
\hline Patella & 2 & & Tibia & 2 & 2 \\
\hline Phalanx 1 & 8 & 1 & Total & 10 & 3 \\
\hline Phalanx 2 & 8 & & & $4.60 \%$ & $7.70 \%$ \\
\hline Phalanx 3 & 8 & & & & \\
\hline Phalanx, vestigial & 24 & & & & \\
\hline Pisiform & 2 & & Total & 219 & 39 \\
\hline Scaphoid & 2 & 1 & & & \\
\hline Skull & 25 & & Not used & & \\
\hline Tooth & 32 & 19 & Phalanx, unspecified & & 1 \\
\hline Triquetral & 2 & & Metapodial & & 3 \\
\hline Unciform & 2 & & & & \\
\hline Total & 147 & 31 & & & \\
\hline
\end{tabular}


Invertebrates of freshwater mussel (Unionidae) and Gastropoda were represented in the assemblage (Table 9). Most were small fragments of shell that could not be further identified. Four of the five taxa of freshwater mussel were identified by Robert Warren of the Illinois State Museum. The most numerous is from the genus Fusconaia, but the species could not be determined. The most common Fusconaia species is the Wabash pigtoe (Fusconaia flava) that inhabits creeks to large rivers in mud, sand, or gravel substrates (Cummings and Mayer 1992). The other species identified include three ridge (Amblema plicata), spike (Elliptio dilatata), mucket (Actinonaias ligamentina), and black sandshell (Ligumia recta). The latter has the most specific habitat requirements of these in that it prefers medium to large rivers with a firm sand or gravel substrate and riffles (Cummings and Mayer 1992). All the valves that could be identified are small and would not have afforded much in the way of sustenance. It is possible the valves were being collected for other uses such as temper for pottery.

The valve identified as three ridge has been modified into a possible shell hoe (Figure 5). It was recovered from Level 3 in Unit N206E201 (Accession \# 2008-327-20). The valve, however, is small in size measuring $65.4 \mathrm{~mm}$ in length and $56.5 \mathrm{~mm}$ in width. A small oval hole measuring $14.3 \mathrm{x} 11.7 \mathrm{~mm}$ has been punched near the beak cavity. There is some chippage on the anterior end near the anterior retractor muscle scar that would have facilitated hafting and the posterior edge of the valve is somewhat squared off and shows wear from use. Hoe blades made from mussel shell valves were more commonly used in the Caddo area than were chipped stone hoes or bison scapulae. Harrington (1960: Plate V) illustrates a hoe from Salts Bluff (3BE18), one of the rockshelters in the northern Arkansas Ozarks, made from a mussel shell valve hafted onto a wooden handle. Perforated mussel shell valves have also been found at Hardman, Caddo Valley Mound, and Cedar Grove in southwest Arkansas (Kay 1984:190. 197-198; Reynolds 2007:53; Williams 1993:138-139).

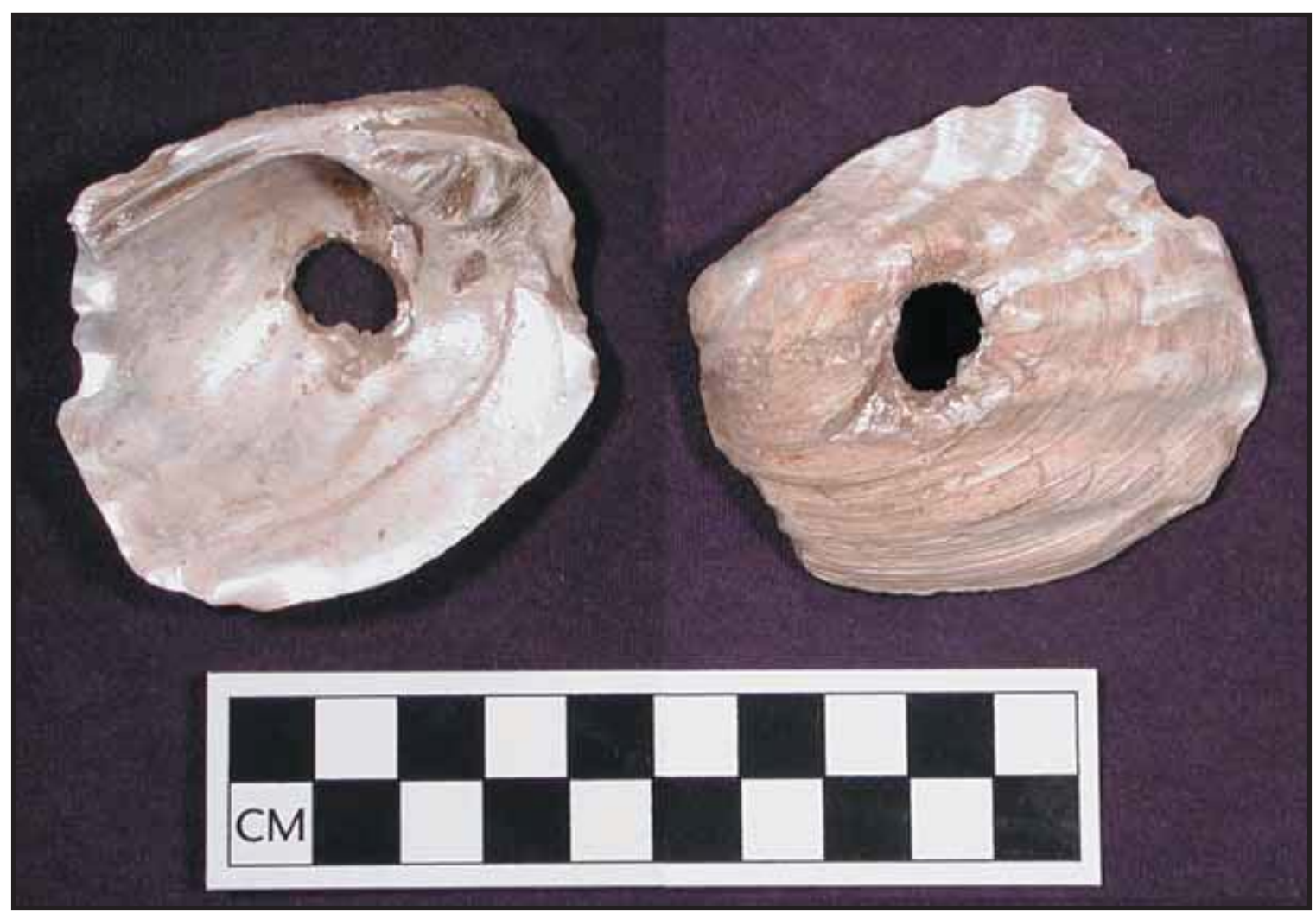

Figure 5. Two views of perforated Amblema plicata valve from Trench 5 (2008-327-20, photo AAS/HSU D_4994, 4996). 


\section{Comparisons}

From the Jones Mill testing in the 1980s, both the botanical and faunal assemblages were sparse, despite the number of features excavated (97, most in a block excavation area on the site's north side, see Figure 2). Most of the floral materials were fragments of wood; amaranth seeds were identified from three features, but hickory nutshell was only identified from one (Bennett 1986:114-115). Only mammal bone was identified, and the only bone identified to species was deer (Bennett 1986:115-117). The lack of identified plant and animal remains is surprising, especially since most of the features excavated were from the Woodland and Caddo period occupations at Jones Mill rather than the earlier Archaic period.

The recovery and analysis of floral and faunal samples as well as radiocarbon dates from modern excavations at Jones Mill was especially important since these were lacking in the earlier work at the site. The two spatially discrete excavation areas, Trenches 3 and 4 and Trench 5, reflect temporal and functional differences between occupations. Archaeological investigations at the site were limited to a relatively small area, however. Thus, the actual scope and magnitude of the Archaic and late prehistoric occupations remain to be more fully explored. Distinctions in diversity, ubiquity and density of macrobotanical and faunal remains between the two areas investigated were readily apparent. At the same time, there was also evidence for strong continuity in one aspect of plant-based foodways, a focus on harvest of seasonal nut masts. Periodic Middle Archaic visitors exploited local sources of novaculite and engaged in tool manufacture, while also purposefully targeting hickory nuts in nearby forests and processing them at the site. Remains of oak, hickory, Osage orange and hackberry wood were sparse in Middle Archaic flotation samples, partially due to preservation factors, although thick, dense nutshells also may have been used as fuel in place of wood. Unfortunately, the faunal assemblage from Jones Mill provides no information on the animal exploitation for the earlier Archaic residents. The faunal remains from the Archaic components consist of indeterminate, calcined fragments.

Foodways of late prehistoric Caddo residents at Jones Mill included a combination of agriculture and foraging for wild plant food resources. At least three taxa of native EC starchy cultigens-maygrass, little barley and erect knotweed - were represented in the seed assemblage, each by a single specimen. Given the presence of Fourche Maline diagnostics at the site, we hoped for some documentation of early domesticates, but the evidence for cultigens, including maize, reflects a later Caddo period occupation. The addition of maize to existing horticultural strategies previously based on indigenous starchy and oil seeds occurred in this region by approximately 1150 B.P. Over time, maize became a staple among the Caddo and gradually replaced traditional small seed crops, a process repeated in many areas of the Eastern Woodlands (cf. Fritz 1984; Perttula 2008; Simon and Parker 2006). In the Trench 5 flotation samples, maize fragments were ubiquitous and abundant in comparison to native cultivated seeds, suggesting that maize was the more important resource. The sample from this component was small and therefore may not be an accurate measure of relative economic significance, but a similar pattern is seen in the region more broadly.

Hickory nuts plainly were a targeted wild food for the Caddo based on all measures of nutshell in the plant assemblage (and hickory nut use continues in some Indian communities up to the present day, see Fritz et al. 2001). Several thin shell fragments and a partial cotyledon suggest that acorns were also harvested. Seasonal fleshy fruits and berries were represented only by a single grape seed, but probably were more valued than this sparse evidence suggests. Forests were the source of non-edible, but nonetheless critical fuel wood, including oak, shortleaf pine and hickory. 
Most of the fauna identified from Trench 5 came from the midden and may be mixed contexts, although a few came from the bases of features that date to the Caddo occupation. It is a small assemblage that suffered from poor preservation although it was much better than the earlier occupations. The Caddo inhabitants of Jones Mill exploited nearby edge and aquatic habitats, the latter most likely being the Ouachita River. Deer would have provided the greatest amount of meat, but it appears fish, turtles, and possibly mussels would have also been an important source of animal protein. Birds do not appear to have been exploited to a great extent.

Beyond the Jones Mill site, there is little firm evidence for foodways from previous excavations in the Middle Ouachita River region for the Archaic period. A Middle Archaic date was obtained on charred nutshell identified by the excavators as hickory nut from a burned rock feature at 3HS551 (Klinger et al. 2001). One of the best discussions of the Archaic and Woodland period lifeways in this region is Schambach's (1998) analysis of WPA-era excavations at the Cooper and Means sites (3HS1, 3HS3), but in the 1930s and 1940s, animal bones and plant fragments were not systematically collected. A list of animals represented by bone and shell from Cooper (with its Middle Archaic to Woodland components) includes white-tailed deer, raccoon, opossum, turkey, rabbit, dog or fox, bobcat, beaver, quail, box turtle, fish, and 15 kinds of freshwater mussel. Fauna from Means (with Woodland and Caddo period components) included deer, raccoon, beaver, bison, turkey, box turtle, and freshwater mussels, and burned cane matting was found in the rectangular Mid-Ouachita phase structure (Schambach 1998:16, 79-80, 108).

More complete knowledge of plant and animal use comes from excavated and reported Caddo components in the Middle Ouachita River region. At Hardman (3CL418), maize was the most abundant plant food, beans and pepo squash are present, native cultigens are poorly represented (little barley and maygrass are present, and the amaranth and chenopod seeds are weedy or wild rather than domesticated). Nutshell from hickory, acorn, and pecan is relatively low, and there are some wild fruit seeds (persimmon, grape, blueberry, cherry, sumac, blackberry/raspberry) (Fritz 1993). White-tailed deer dominated and fish and mussels were abundant and diverse at Hardman, while small mammals, birds, reptiles, and amphibians were relatively sparse (Styles and White 1993). At Helm (3HS449), bone preservation was poor, and the faunal assemblage was not as diverse. Fish, birds, turtle, and frog/toad are present but the assemblage is dominated by deer and other mammals (Scott 2000). The botanical materials were fragmented, but were again dominated by maize, with nutshell (thick hickory, acorn), domesticated beans and pepo squash, maygrass, and wild or weedy types of chenopod, amaranth, knotweed, and sumpweed present, as well as several wild starchy seeded plants (ragweed, purslane, dropseed, dock) and wild fruits (nightshade, grape, persimmon, passionflower, and raspberry/ blackberry) (Powell and Lopinot 2000). With the exception of the mussel shell, floral and faunal assemblages from the contemporaneous Caddo Valley Mound (3CL593) on the lower Caddo River have not yet been analyzed (Reynolds 2007). Ten species of freshwater mussel were identified there, including a perforated mussel shell valve (Scott 2007).

Further west in the Ouachita Mountains region, botanical materials from Standridge and Winding Stair have been analyzed but faunal remains were seldom recovered. A well-preserved and diverse botanical assemblage from Winding Stair (3MN496) was dominated by domesticated maize, followed by wild hickory nuts and acorns, chenopod that was wild or weedy rather than domesticated, and wild fruits (persimmons, grapes) (Williams 2000b). Maize likewise dominated the plant remains from Standridge (3MN53), with beans the only other cultigen identified. Persimmon seeds were also abundant, and a variety of nuts-hickory, black walnut, acorn, pignut, and shagbark hickory—were found (Early 1988). 


\section{Summary and Conclusions}

While the recovery of flora and fauna from the Middle Archaic Trench 3 and 4 samples was disappointing, it is clear that hickory nut collecting and processing was an important part of the foodways during this time. These nuts are ready to harvest in the fall, and would provide a storable and nutritious food supply over the winter. An argument could be made for hunting, probably deer, during fall and winter too, but this is an inference based on the dart points with distal impact fractures. If Middle Archaic residents of Jones Mill were netfishing with the notched pebble netsinkers found at the site, they may have congregated here in the late spring/early summer to take advantage of fish spawning in the nearby Ouachita River, but again, this is conjecture.

The information from the Caddo period occupation based on Trench 5 is more complete. Deer and turkey would be in their prime in the late fall/early winter but could have been hunted year round. Nutshell such as hickory would be collected in the fall as well. Fish may indicate warmer months, as would turtles. Preparing fields for crops would be done in spring, with harvests in the summer. The food evidence, plus the remains of a house dating to $\mathrm{AD} 1450$, shows a more substantial community of people farming, fishing, hunting, and living at Jones Mill throughout the year.

Limited archaeological excavations at the Jones Mill site has provided tantalizing insights into contrasting patterns of prehistoric plant and animal use at a single locality within the Ouachita River Valley from about $6000 \mathrm{BC}$ to $1450 \mathrm{AD}$. Analysis of artifacts and features from the excavations is on-going, and further details of the lifeways of the ancient inhabitants of Jones Mill will be forthcoming.

\section{Acknowledgments}

This project is supported in part by a grant from the Arkansas Humanities Council and the Department of Arkansas Heritage. Additional support for research at the Jones Mill site comes from the Arkansas Archeological Society's Archeological Research Fund. Excavations at the site took place in 2007 and 2008 with crews of professionals, volunteers, and students from the Arkansas Archeological Survey, the Arkansas Archeological Society, and Henderson State University and University of Arkansas. Lab assistance was provided by Amanda Brock, Mary Ann Goodman, Florence Davis, Judy Thye, and Elizabeth Sorensen. The landowner, Entergy Arkansas, Inc., is appreciated both for extending permission for the excavations but also for continued protection of this important site.

\section{References Cited}

Asch, D. L. and N. B. Asch

1985 Archaeobotany of the Campbell Hollow Archaic Occupations. In The Campbell Hollow Archaic Occupations: A Study of Intrasite Spatial Structure in the Lower Illinois Valley, edited by C. Russell Stafford, pp. 82-107. Research Series, Vol. 4. Center for American Archeology, Kampsville, Illinois.

Baker, C. M.

1974 A Study of Aboriginal Novaculite Exploitation in the Ouachita Mountains of South-Central Arkansas. Unpubl. M. A. Thesis, Department of Anthropology, University of Arkansas, Fayetteville. 


\section{References Cited (cont.)}

Bennett, W. J., Jr., with contributions from B. Burnett, C. Clark, A. F. Gettys, R. Hollaway, M. Marks, J. Miller, L. Smith, J. B. Sollberger, R. Stewart, and J. Watkins

1986 Investigations at 3HS28, the Jones Mill Site. Report No. 25, Archeological Assessments, Inc., Nashville, Arkansas.

Bohlen, H. D.

1989 The Birds of Illinois. Indiana University Press, Bloomington.

Brock, A.

2009 Field School Excavations at Jones Mill, 2007. Field Notes (Newsletter of the Arkansas Archeological Society) 350:3-4.

Brookes, S. O.

1999 Prehistoric Exchange in Mississippi, 10,000 B.C. - A.D. 1600. In Raw Materials and Exchange in the Mid-South, edited by E. Peacock and S. O. Brookes, pp. 86-94. Archaeological Report No. 29, Mississippi Department of Archives and History, Jackson, Mississippi.

Chaplin, R. E.

1971 The Study of Animal Bones from Archaeological Sites. Seminar Press, New York.

Chapman, J. S.

2004 Cultural Resources Survey of Three Items in the Ouachita River, Hot Spring County, Arkansas, as Part of a Section 1135 Environmental Restoration Project. Final Report, Panamerican Consultants, Inc., Memphis, Tennessee.

Cummings, K. S. and C. A. Mayer

1992 Field Guide to Freshwater Mussels of the Midwest. Illinois Natural History Survey, Manual 5, Champaign.

Driver, J. C.

1992 Identification, Classification and Zooarchaeology. Circaea 9(1):35-47.

Early, A. M.

1988 Standridge: Caddoan Settlement in a Mountain Environment. Research Series 29, Arkansas Archeological Survey, Fayetteville.

2000 The Caddo and the Forest. In Forest Farmsteads: A Millennium of Human Occupation at Winding Stair in the Ouachita Mountains, edited by A. M. Early, pp. 93-110. Research Series 57, Arkansas Archeological Survey, Fayetteville.

2002 The Mid-Ouachita Phase. Field Notes (Newsletter of the Arkansas Archeological Society) 305:1013.

Etchieson, M.

1997 Prehistoric Novaculite Quarries in the Ouachita Mountains. Paper presented at the Annual Meeting of the Society for American Archaeology, Nashville, TN. 


\section{References Cited (cont.)}

Fritz, G. J.

1984 Identification of Cultigen Amaranth and Chenopod from Rockshelter Sites Northwest Arkansas. American Antiquity 49(3):558-572.

1993 Archeobotanical Analysis. In Caddoan Saltmakers in the Ouachita Valley: The Hardman Site, edited by A. M. Early, pp. 159-168. Research Series 43, Arkansas Archeological Survey, Fayetteville.

Fritz, G. J., V. Drywater Whitekiller, and J. W. McIntosh

2001 Ethnobotany of Ku-Nu-Che: Cherokee Hickory Nut Soup. Journal of Ethnobiology 21(2):1-27.

Gardner, P. S.

1997 The Ecological Structure and Behavioral Implications of Mast Exploitation Strategies. In People, Plants and Landscapes: Studies in Paleoethnobotany, edited by Kristen J. Gremillion, pp. 161-178. The University of Alabama Press, Tuscaloosa.

Gautier, A.

1984 How Do We Count These Bones? Let Me Count the Ways. Problems of Archaeozoological Quantification. In Animals and Archaeology, Vol. 4, edited by C. Grigson and J. Clutton-Brock, pp. 237-251. BAR International Series 227, British Archaeological Reports, Oxford.

Gibson, J. L.

1994 Empirical Characterization of Exchange Systems in Lower Mississippi Valley Prehistory. In Prehistoric Exchange Systems in North America, edited by T. G. Baugh and J. E. Ericson, pp. 127-175. Plenum Press, New York.

1999 Swamp Exchange and the Walled Mart: Poverty Point's Rock Business. In Raw Materials and Exchange in the Mid-South, edited by E. Peacock and S. 0. Brookes, pp. 57-63. Archaeological Report No. 29, Mississippi Department of Archives and History, Jackson, Mississippi.

Gilbert, B. M.

1990 Mammalian Osteology. Missouri Archaeological Society, Columbia, MO.

Grayson, D. K.

1984 Quantitative Zooarchaeology: Topics in the Analysis of Archaeological Faunas. Academic Press, New York.

Harrington, M. R.

1920 Certain Caddo Sites in Arkansas. Indian Notes and Monographs, Museum of the American Indian, Heye Foundation, New York.

1960 The Ozark Bluff-Dwellers. Indian Notes and Monographs, Vol. XII. Museum of the American Indian, Heye Foundation, New York.

Hester, T. R., editor

1991 The Burned Rock Middens of Texas: An Archeological Symposium. Studies in Archeology 13, Texas Archeological Research Laboratory, University of Texas, Austin.

Hoadley, R. B.

1990 Identifying Wood: Accurate Results with Simple Tools. The Taunton Press, Newtown, Connecticut. 


\section{References Cited (cont.)}

Hoffmeister, D. F.

1989 Mammals of Illinois. University of Illinois Press, Urbana.

Holmes, W. H.

1891 Aboriginal Novaculite Quarries in Garland County, Arkansas. American Anthropologist 4 (old series):313-316.

1919 Handbook of Aboriginal American Antiquities, Part I, Introductory, The Lithic Industries. Smithsonian Institution, Bureau of American Ethnology Bulletin 60, Washington, D.C., reprinted 1974, Burt Franklin, New York, NY.

Integrated Taxonomic Information System

2010 Integrated Taxonomic Information System. Website http://www.itis.gov .

Jackson, H. E. and S. L. Scott

2001 Archaic Faunal Utilization in the Louisiana Bottomlands. Southeastern Archaeology 20(2):187196.

Jeter, M. D. and H. E. Jackson

1994 Poverty Point Extraction and Exchange: The Arkansas Lithic Connections. In Exchange in the Lower Mississippi Valley and Contiguous Areas at 1100 B.C., edited by J. L. Gibson. Louisiana Archaeology 17(1990):133-206.

Jenney, W. P.

1891 Ancient Novaculite Mines near Magnet Cove, Hot Springs County, Arkansas. American Anthropologist 4 (old series):316-318.

Johnson, J. K.

1981 Lithic Procurement and Utilization Trajectories: Analysis, Yellow Creek Nuclear Power Plant Site, Tishomingo County, Mississippi, Volume II. Archaeological Papers of the Center for Archaeological Research No. 1, University of Mississippi, University.

Johnson, T. R.

1992 The Amphibians and Reptiles of Missouri. Missouri Department of Conservation, Jefferson City.

Kay, M.

1984 Late Caddo Subtractive Technology in the Red River Basin. In Cedar Grove: An Interdisciplinary Investigation of a Late Caddo Farmstead in the Red River Valley, edited by N. L. Trubowitz, pp. 174206. Research Series No. 23, Arkansas Archeological Survey, Fayetteville.

Kidder, T. R.

1997 Sugar Reflotation: An Alternative Method for Sorting Flotation-Derived Heavy Fraction Samples. Journal of Field Archaeology 24(1):39-45.

Klein, R. G. and K. Cruz-Uribe 1984 The Analysis of Animal Bones from Archaeological Sites. University of Chicago Press, Chicago. 


\section{References Cited (cont.)}

Klinger, T. C., J. A. Ross, D. R. Dickson, J. L. Gray, IV, and G. G. Dunn

2001 Malvern Unit, Arkansas Department of Corrections Facility, Historic Properties Overview of a Proposed Prison Facility in the Ozark-Arkansas-Ouachita Region, Hot Spring County, Arkansas. Historic Preservation Associates, Report \#01-27, Fayetteville, Arkansas.

Marshall, F. and T. Pilgram

1993 NISP vs. MNI in Quantification of Body Part Representation. American Antiquity 58(2):261-269.

Martin, A. C. and W. D. Barkley

1961 Seed Identification Manual. University of California Press, Berkley.

Pearsall, D. M.

1989 Paleoethnobotany: A Handbook of Procedures. Academic Press, New York

Perttula, T. K.

2008 Caddo Agriculture on the Western Frontier of the Eastern Woodlands. Plains Anthropologist 53(205):79-105.

Perttula, T. K., M. B. Trubitt, and J. S. Girard

n.d. The Use of Shell-Tempered Pottery in the Caddo Area of the Southeastern U.S. Ms. under review for Southeastern Archaeology.

Pflieger, W. L.

1975 The Fishes of Missouri. Missouri Department of Conservation, Jefferson City.

Powell, G. S. and N. H. Lopinot

2000 Archeological Plant Remains from the Helm Site. In Data Recovery at the Helm Site, 3HS449, Hot Spring County, Arkansas, by R. H. Lafferty III, A. Early, M. C. Sierzchula, M. C. Hill, G. S. Powell and N. H. Lopinot, L. S. Cummings, S. L. Scott, S. K. Nash, and T. K. Perttula, pp. 187-229. MCRA Report 2000-1. Mid-Continental Research Associates, Inc., Lowell, Arkansas.

Purdue, J. A.

1983 Epiphyseal Closure in White-tailed Deer. Journal of Wildlife Management 47(4):1207-1213.

Reitz, E. J. and E. S. Wing

2008 Zooarchaeology. Cambridge University Press, Cambridge, United Kingdom.

Reynolds, M. D.

2007 Preliminary Report on Salvage Excavations at 3CL593. Limited distribution report, Arkansas Archeological Survey, HSU Research Station, Arkadelphia.

Rolingson, M. A. and J. M. Howard

1997 Igneous Lithics of Central Arkansas: Identification, Sources, and Artifact Distribution. Southeastern Archaeology 16(1):33-50. 


\section{References Cited (cont.)}

Schambach, F. F.

1998 Pre-Caddoan Cultures in the Trans-Mississippi South: A Beginning Sequence. Research Series 53, Arkansas Archeological Survey, Fayetteville.

2003 Osage Orange Bows, Indian Horses, and the Blackland Prairie of Northeastern Texas. In Blackland Prairies of the Gulf Coastal Plain: Nature, Culture, and Sustainability, edited by E. Peacock and T. Schauwecker, pp. 212-236. University of Alabama Press, Tuscaloosa.

Schwartz, C. W. and E. R. Schwartz

1981 The Wild Mammals of Missouri. University of Missouri Press and Missouri Department of Conservation, Columbia.

Scott, R. J.

2007 Mussel Shell. In Preliminary Report on Salvage Excavations at 3CL593, by M. D. Reynolds, Appendix

C. Limited distribution report, Arkansas Archeological Survey, HSU Research Station, Arkadelphia.

Scott, S. L.

2000 Vertebrate Faunal Remains from the Helm Site (3HS449). In Data Recovery at the Helm Site, 3HS449, Hot Spring County, Arkansas, by R. H. Lafferty III, A. Early, M. C. Sierzchula, M. C. Hill, G. S. Powell and N. H. Lopinot, L. S. Cummings, S. L. Scott, S. K. Nash, and T. K. Perttula, pp. 249-253. MCRA Report 2000-1. Mid-Continental Research Associates, Inc., Lowell, Arkansas.

Severinghaus, C. W.

1949 Tooth Development and Wear as Criteria of Age in White-tailed Deer. Journal of Wildlife Management 13:195-216.

Simon, M. L. and K. E. Parker

2006 Prehistoric Plant Use in the American Bottom: New Thoughts and Interpretations. Southeastern Archaeology 25(2):212-257.

Stafford, C. R.

1991 Archaic Period Logistical Foraging Strategies in West-Central Illinois. Midcontinental Journal of Archaeology 16(2):212-246.

Styles, B. W. and K. White

1993 Faunal Analysis. In Caddoan Saltmakers in the Ouachita Valley: The Hardman Site, edited by A. M. Early, pp. 145-158. Research Series 43, Arkansas Archeological Survey, Fayetteville.

Titmus, G. L. and J. C. Woods

1986 An Experimental Study of Projectile Point Fracture Patterns. Journal of California and Great Basin Anthropology 8(1):37-49. 


\section{References Cited (cont.)}

Trubitt, M. B.

2005 Mapping a Novaculite Quarry in Hot Springs National Park. Caddoan Archeology Journal 14:17-33.

2007 The Organization of Novaculite Tool Production: Quarry-Workshop Debitage Comparisons. Caddo Archeology Journal 16:71-89.

2008 Something New on the Archaic: Highlights from the 2007-2008 Training Programs. Field Notes (Newsletter of the Arkansas Archeological Society) 345: 4-7.

2009a Investigating Middle Archaic at the Jones Mill Site. The Arkansas Archeologist (Bulletin of the Arkansas Archeological Society) 48:71-84.

2009b Putting an Age on the Archaic at Jones Mill. Field Notes (Newsletter of the Arkansas Archeological Society) 349: 3-7.

2009c Burning and Burying Buildings: Exploring Variation in Caddo Architecture in Southwest Arkansas. Southeastern Archaeology 28(2):233-247.

2011 Another Archaic Period Date from Jones Mill. Field Notes (Newsletter of the Arkansas Archeological Society). Forthcoming in next issue.

Trubitt, M. B., T. Green, and A. Early

2004 A Research Design for Investigating Novaculite Quarry Sites in the Ouachita Mountains. The Arkansas Archeologist (Bulletin of the Arkansas Archeological Society) 43:17-62.

Uerpmann, H.-P.

1973 Animal Bone Finds and Economic Archaeology: A Critical Study of 'Osteo-archaeological' Method. World Archaeology 4(3):

United States Department of Agriculture, Natural Resources Conservation Service

2010 Fact Sheets and Plant Guides. USDA, Natural Resources Conservation Service. Website http://www. plants.usda.gov/java/factSheet.

Webb, C. H.

1977 The Poverty Point Culture. Geoscience and Man, Volume XVII, School of Geoscience, Louisiana State University, Baton Rouge.

Williams, G. I., Jr.

1993 Lithic, Bone, Shell, and Historic Artifacts. In Caddoan Saltmakers in the Ouachita Valley: The Hardman Site, edited by A. M. Early, pp. 119-144. Research Series 43, Arkansas Archeological Survey, Fayetteville.

Williams, M. L.

2000a Evidence for Medicinal Plants in the Paloeethnobotanical Record of the Eastern United States during the Late Woodland through Mississippian Periods. Ph.D. dissertation, Department of Anthropology, Washington University, St. Louis.

2000b Ethnobotanical Analysis. In Forest Farmsteads: A Millennium of Human Occupation at Winding Stair in the Ouachita Mountains, edited by A. M. Early, pp. 111-122. Research Series 57, Arkansas Archeological Survey, Fayetteville. 